\title{
Influence of store brands on variety-seeking behaviour of consumers in Mexico
}

\author{
Rajagopal \\ EGADE Business School, \\ Mexico City Campus, \\ 222, Calle del Puente, Col. Ejidos de Huipulco, \\ Tlalpan 14380 DF, Mexico \\ E-mail: rajagopal@itesm.mx
}

\begin{abstract}
The variety-seeking behaviour and the store choice among the consumers have been discussed extensively in the previous research contributions from the stochastic point of view. This study argues that although consumers are seeking novelty and unexpectedness in a store that they have not bought before, their purchase will be selective, in reference to the empirical investigation. This study has been conducted in Mexican retail business environment with a focus to explore the tendency of decision-making of consumers towards buying unfamiliar stores in considering the importance of store name. The discussions in this paper have been woven around the issues of perceived risk, perceived store difference, association of store name and customer values as major influencing factors in making buying decisions towards unfamiliar stores. This study reveals that the perceptions on store name in reference to store risk and store differences have been the prime factors in making buying decision for new stores among the consumers. Consumers also ascertain the store name associated with the unfamiliar stores as they feel high risk averse and entangle in decision-making with perceived store differences.
\end{abstract}

Keywords: consumer behaviour; store personality; store loyalty; brand perceptions; decision-making; customer value.

Reference to this paper should be made as follows: Rajagopal (2011) 'Influence of store brands on variety-seeking behaviour of consumers in Mexico', Int. J. Built Environment and Asset Management, Vol. 1, No. 1, pp.56-73.

Biographical notes: Rajagopal is a Professor of Marketing at the Graduate Business School (EGADE) of Monterrey Institute of Technology and Higher Education (ITESM), Mexico City Campus. He is a Fellow of the Royal Society for Encouragement of Arts, Manufacture and Commerce, a Fellow of the Institute of Operations Management and a Fellow of the Chartered Management Institute. He has been conferred as National Researcher Level 2 of the Mexican National System of Researchers. He has to his credit 34 books and over 400 research contributions including papers in international refereed journals, refereed conferences papers, research reports, working papers and business cases published in referred academic outlets.

Copyright (C) 2011 Inderscience Enterprises Ltd. 


\section{Introduction}

In view of globalisation, many international companies are experimenting innovative strategies to make their marketing channels more flexible and responsive to avoid rush hour stock-outs and customer dissatisfaction. However, the dynamics of marketing channels and appropriate point of purchase convergence strategies of marketing channels and firm could help in developing positive consumer response towards products and services of the firm. International companies are developing new hybrid marketing systems that entail architecture of marketing channels with a focus on optimising consumer response. Such system offers larger market coverage and reduced costs, through hybrid grid, a map that illustrates the combination of channels and tasks that will optimise cost and coverage (e.g. Moriarty and Moran, 1990). In this process, it is necessary that companies should select market channels that serve the market segment and not just represent a geographic area, and are catalytic in driving consumer response at various stages of product life cycle.

Traditional research regards variety seeking as non-purposeful and random behaviour (Bass, 1974; Huber and Reibestein, 1978). This paper argues that although consumers are seeking novelty and unexpectedness in a store that they have not bought before, their purchase will be selective. In other words, they will not simply pick up any encountered store that they have not bought before and their store choice will be constrained by certain factors. Among these factors, an important one is the company name. In this paper, an attempt is made to explore the situations under which the store name is considered by the consumers as a principal driver in making buying decisions towards the products of unfamiliar stores.

\section{Review of literature}

\subsection{Cognitive behaviour and store equity}

Strong store equity allows the companies to retain customers better, service their needs more effectively and increase profits. Store equity can be increased by successfully implementing and managing an ongoing relationship marketing effort by offering value to the customer and listening to their needs. Disregarding the edge that the storecustomer relationship offers in the market place and not utilising the benefits and goodwill that the relationship creates will surely lead to failure in the long run. The central store idea may be static among the entire customer and prospect bases, but the total sum of the store idea or perception is rooted in the customer's experiences with the store itself, and all its messages, interactions, etc. In the market, a strong store will be considered to have high store equity. The store equity will be higher if the store loyalty, awareness, perceived quality; strong channel relationships and association of trademarks and patents are higher. High store equity provides many competitive advantages to the company. The store equity may be understood as the highest value paid for the store names during buy-outs and mergers. This concept may be defined as the incremental value of a business above the value of its physical assets due to the market positioning achieved by its store and the extension potential of the store (Tauber, 1998). 
A new approach for measuring, analysing and predicting a store's equity in a product market defines the store equity at the firm level as the incremental profit per year obtained by the store in comparison to a store with the same product and price but with minimal store-building efforts. At the customer level, it determines the difference between an individual customer's overall choice probability for the store and his or her choice probability for the underlying product with merely its push-based availability and awareness. The approach takes into account three sources of store equity-store awareness, attribute perception biases and non-attribute preference - and reveals how much each of the three sources contributes to store equity. In addition, the proposed method incorporates the impact of store equity on enhancing the store's availability. The method provides what-if analysis capabilities to predict the likely impacts of alternative approaches to enhance a store's equity.

\subsection{Store loyalty and consumer decision-making}

The store management has developed to take advantage of new loyalty marketing vehicles. To build and maintain consumer loyalty, store managers are supplementing their mass media advertising with more direct communications, through direct and interactive methods, internet communications and other innovative channels of distribution (Baldinger and Robinson, 1996; Pearson, 1996). Simultaneously, however, store managers have to face more threats to their stores, especially parity responses from competitors. Store loyalty can yield significant marketing advantages including reduced marketing costs, greater trade leverage (Aaker, 1991), resistance among loyal consumers to competitors' propositions (Dick and Basu, 1994) and higher profits (Reichheld, 1996). Chaudhuri and Holbrook (2001) have shown that store loyalty is a key link affecting market share and relative price. Thus, store loyalty is justifiably included in the approaches advocated by other researchers (e.g. Aaker and Joachimsthaler, 2000; Ambler, 2000; Blackston, 1992; Rust et al., 2000). When operationalising store loyalty, Jacoby and Kyner (1973), Jacoby and Chestnut (1978) and Oliver (1999) argue it is unwise to infer loyalty solely from repetitive purchase patterns (behavioural loyalty).

Preference for convenience, novelty, chance encounters and repertoire buying behaviour are but some reasons for this. Jacoby and Kyner (1973) brought together the two 'opposing' approaches to store loyalty, namely behavioural and attitudinal loyalty, integrating them into their definition, as the store loyalty is 'the biased (non-random) behavioural response (purchase) expressed over time by some decision-making unit with respect to one or more alternative stores out of a set of such stores, and is a function of psychological (decision-making and evaluative) processes'. Oliver (1999) argues consumers become loyal by progressing from a cognitive to an affective and finally to a conative phase. In line with previous research showing that in service markets attitudinal loyalty measures are more sensitive than behavioural loyalty measures, another study explored to operationalise loyalty by questioning consumers about affective and conative loyalty (Rundle-Thiele and Bennett, 2001). Following other researchers like Dall'Olmo et al. (1997), the consumers were asked as how much they liked the corporate store (affective loyalty), as well as whether they would consider using other products from the corporation and whether they would recommend the corporate store to others (conative loyalty). Readers interested in a more detailed review on operational and conceptual aspects of store loyalty should consult Odin et al. (2001). 
The in-store environment variables in the shopping malls driving impulsive buying behaviour include display of point of sales posters, exhibiting promoting discounts and cheaper prices, while the atmosphere engagement referring to enjoyment, elegance and attractiveness is conveyed by ambience inside the shopping mall. Such behavioural drivers may also be referred as in-store promotional effect and atmospheric effect (Teller, 2008). Five essential qualities of aesthetic judgement, which include interest, subjectivity, exclusivity, thoughtfulness and internality, need to be nurtured among consumers to develop conviction in buying. The quality of aesthetic judgement driven by in-store aura and arousal on new products, exercised by the customers in association with the sales promoters, determines the extent to which new products and brands promoted enhance quality of life (Dobson, 2007).

\subsection{Personality traits and buying behaviour of customers}

Consumers often anthropomorphise stores by endowing them with personality traits, and marketers often create or reinforce these perceptions by their store positioning. Store personality traits provide symbolic meaning or emotional value that can contribute to consumers' store preferences and can be more enduring than functional attributes. Successfully positioning a store's personality within a product category requires measurement models that are able to disentangle a store's unique personality traits from those traits that are common to all stores in the product category. Consumers perceive the store on dimensions that typically capture a person's personality and extend that to the domain of stores. The dimensions of store personality are defined by extending the dimensions of human personality to the domain of stores. One way to conceptualise and measure human personality is the trait approach, which states that personality is a set of traits (Anderson and Robin, 1986). A trait is defined as 'any distinguishable, relatively enduring way in which one individual differs from others' (Guilford, 1973).

Human personality traits are determined by multi-dimensional factors such as the individual's behaviour, appearance, attitude and beliefs, and demographic characteristics. Based on the trait theory, researchers have concluded that there are five stable personality dimensions, also called the 'big five' human personality dimensions (Batra et al., 1993). The relationship between the store and customer is largely governed by the psychographic variables that can be measured broadly by the closeness and farness of the personalities of store and customer. The type of relationship that customers possess with the stores based on the loyalty levels is an extremely significant parameter for the marketers. Duncan and Moriarty (1998) point out that each of the new-generation marketing approaches include customer focused, market-driven, outside-in, one-to-one marketing, data-driven marketing, relationship marketing, integrated marketing and integrated marketing communications that emphasise two-way communication through better listening to customers and the idea that communication before, during and after transactions can build or destroy important store relationships.

Advertising is heavily used in this process of personality creation. This follows logically from the fact that personalities are particularly useful for the creation of store associations. Store associations influence the 'evaluation of alternatives' stage in basic consumer buying behaviour models. In this stage, and for these goals, advertising is considered to be the most effective communication tools (Brassington and Pettitt, 2002). Perhaps the most visible and best known way of personality creations is by means of celebrity endorsers. Public heroes, sports people, pop stars and movie stars are hired to 
lend their personality to a store but this practice goes back to at least for a century (Erdogan and Baker, 2000). The practice is still growing in popularity today. Yet, basically all advertising influences the store personality, not only when an endorser is used. In the process of personality creation, in reference to advertising and marketing communication approaches are largely used to create store personality (Redenbach, 2000). It may be observed that a general model of advertising has been integrated with a model of store personality creation as discussed in some of the studies. Based on that model a number of propositions are derived and presented thorough analysis of the role of store personality in the creation of store equity, thereby linking the core issue to one of general and increasing importance. Agarwal and Rao (1996) along with Mackay (2001) contend that a variety of components must characterise store equity, and as Table 1 shows, multi-item measures are common.

Table 1 Significance tests and clustered mean values of the variables under study

\begin{tabular}{lcccccc}
\hline & & \multicolumn{4}{c}{ Clusters' means } & Hypothesis \\
\cline { 3 - 5 } Variable segments $^{\mathrm{a}}$ & Cronbach $(\alpha)$ & $C_{1}$ & $C_{2}$ & $C_{3}$ & tested \\
\hline Risk perceived by the customers (4) & 0.735 & 4.97 & 6.12 & 5.82 & $\mathrm{H} 1$ \\
Perceived store difference (5) & 0.714 & 5.71 & 7.52 & 6.24 & $\mathrm{H} 2$, \\
& & & & & $\mathrm{H} 3$ \\
Store and company name association (5) & 0.781 & 4.43 & 5.84 & 5.69 & $\mathrm{H} 3$ \\
$\begin{array}{l}\text { Customer value enhancement through } \\
\text { store name and company association (2) }\end{array}$ & 0.645 & 4.05 & 4.68 & 5.14 & $\mathrm{H} 4$ \\
\hline
\end{tabular}

${ }^{a}$ Figures in parentheses indicate the number variables in the segment.

\subsection{Store association and variety-seeking behaviour}

There is limited research available in the domain of risk aversion, self-confidence, variety seeking, convenience orientation, flexibility, demographics, etc. and all differ measurably and significantly between shopping modes. Though the practical and theoretical implications are largely pursued but there exists the paucity of conceptual models that attempt to identify channel characteristics or to link them to behavioural outcomes (Michaelidou et al., 2005). Variety seeking has been observed in many consumer products and it has been identified as a key determinant factor in store switching. This type of behaviour is thought to be explained by experiential or hedonic motives rather than by utilitarian aspects of consumption. In another study, it has been discussed that among the range of strategies available to a company, line extensions are an important way to keep a store alive and to realise incremental financial growth. Of all line extensions, those involving new flavours and new packaging/sizes were most successful. Extensions that improved product quality were found to be unsuccessful. The market variables such as level of competition, retailer power and variety-seeking behavior, all showed a negative influence on line extension success (Nijssen, 1999). The behaviour of variety seeking among the consumers has been divided into derived or direct variations (McAlister and Pessemier, 1982). The consumer behaviour emerging out of external or internal forces that have no concern with a preference for change in and of itself may be referred as derived varied behavior, while direct varied behaviour has been defined in reference to 'novelty', 'unexpectedness', 'change' and 'complexity' as they are pursued to gain inherent satisfaction. In a study, the influence of product-category level attributes 
were examined and six influential factors, which are involvement, purchase frequency, perceived store difference, hedonic feature, strength of preference and purchase history, have been identified (Van Trijp et al., 1996).

Over the past two decades, marketing scientists in academia and industry have employed consumer choice models calibrated using supermarket scanner data to assess the impact of price and promotion on consumer choice, and they continue to do so today. Despite the extensive usage of scanner panel data for choice modelling, very little is known about the impact of data preparation strategies on the results of modelling efforts. In most cases, scanner panel data is pruned prior to model estimation to eliminate less significant stores, sizes, product forms, etc., as well as households with purchase histories not long enough to provide information on consumer behaviour concepts such as loyalty, variety seeking and store consideration. A study conducts an extensive simulation experiment to investigate the effects of data pruning and entity aggregation strategies on estimated price and promotion sensitivities (Andrews and Currim, 2002). The results show that data preparation strategies can result in significant bias in estimated parameters. Intrinsic variety seeking has been analysed as an individual consumer's trait affecting consumers' varied behaviour. However, very little research has been done on the consumer service sector. In this paper, the authors explore the negative role of variety seeking on customer retention for services. This basic hypothesis is tested through structural equation modelling applied to an empirical study of food service at three universities. The results support the hypothesis: variety seeking negatively affects customer retention and lessens the impact of the management efforts to improve service quality and customer satisfaction (Berné et al., 2001).

\section{Theoretical motivation}

A number of theories have been proposed to explain variety-seeking behaviour. Theories explaining intra-individual differences mainly focus on the nature of the product. It has been argued that consumers are more likely to seek variety in the product with attributes that interact with the senses in reference to the theory of sensory-specific satiety (Inman, 2001). Besides, the traditional theories regard variety seeking as non-purposeful and random behaviour of the consumers (Bass, 1974; Huber and Reibestein, 1978). Optimal stimulation level (OSL) and dynamic attribute satiation (DAS) are most distinguished among them (Berlyne, 1960; Leuba, 1955; McAlister, 1982; Venkatesan, 1973; Zuckerman, 1979). Although the two models deal with the issue through different perspectives, their underlying rationale is the same, that consumers' boredom or satiation with certain attributes in an item will lead to their search for variety in another item. Both models assume that consumers can clearly appreciate the product attributes and therefore can identify the variety that they need. This assumption may be true if consumers have a good knowledge of the items in which the variety is to be sought, particularly when consumers have experience of using these items. In another model, which deals with switching behaviour among familiar items discusses that a consumer's set of items from which to choose is not static, however, and it will gradually expand to include new items and remove old items (McAlister, 1982). Therefore, the question is how consumers will process information on a new item which they have never used before. So far, little research effort has been directed to examine the determinants of consumers' purchase of 
a new item. According to the theory of OSL, every person prefers an ideal level of stimulation.

The level of stimulation is determined by novelty, surprise, change, ambiguity, complexity, incongruity and uncertainty that are associated with a stimulus or situation. Further to OSL model, the concept of DAS has been developed, which makes an important contribution in explaining variety-seeking behaviour. The underlying notion is that consumers satiate on the attributes provided by a chosen alternative, and are therefore less likely to immediately repurchase it. The variety-seeking behaviour occurs where exists the incongruity towards harmony, being incompatible, inconsistent or absurdly combined as one consumes the same product attribute (McAlister, 1982). The variety-seeking behaviour is also influenced by the novelty of the products and services. In spite of conceptual analyses emphasising the need for novelty and unexpectedness to make consumers try unfamiliar stores, few studies have examined consumers' information processing in the decision to purchase a store that they have not bought before (Berlyne, 1960; Maddi, 1968; Venkatesan, 1973). The variety-seeking behaviour among the customers is also stimulated by the availability of the in-store availability of the products. Bliss (1988) after surveying existing models of retailing discusses on the idea that the retailer saves its consumers costs by assembling goods in one place. This introduces an essential non-convexity and importantly affects the conditions under which shops compete with each other and the constraints on their value attributes. The value of a consumer may be defined in reference to a firm, as the expected performance measures are based on key assumptions concerning retention rate and profit margin, and the consumer value also tracks market value of these firms over time. The value of all consumers is determined by the acquisition rate and cost of acquiring new consumers as discussed by Gupta et al. (2003).

The analytical framework in the following text is discussed also in reference to the prospect theory developed by Tversky and Kahnman (1981) towards framing decisions and understanding the dynamics of choices that consumers may exercise to optimise their satisfaction and ultimate value. The value measurements have been used as one of the principal tools to assess the trend of consumer behaviour for the non-conventional products. The value syndrome influences the individual and group decisions in retail and bulk deals, and conditionalises the decision process of consumers. The conditional consumption behaviour suggests that the consumption depends heavily on the utility function and on the source of uncertainty (Carroll and Kimball, 1996; Deaton, 1992). The dynamics of retail consumption behaviour may be expressed as:

$$
c_{\mathrm{t}}=\alpha_{0}+\alpha_{1} y_{\mathrm{t}}+\alpha_{2} w_{\mathrm{t}}+u_{\mathrm{t}}
$$

where $c_{\mathrm{t}}$ is a $\log$ of real per capita total consumption, $y_{\mathrm{t}}$ is the $\log$ of real per capita disposal income, $w_{\mathrm{t}}$ is the per capita expenditure on buying and $u$ denotes the random error term. Under this assumption, $c_{\mathrm{t}}, y_{\mathrm{t}}$ and $w_{\mathrm{t}}$ are co-integrated, $u_{\mathrm{t}} \leq 0$, in the process of measuring the consumer behaviour in reference to preference variables leading to price and non-price determinants, the dependent factor is the rate of change in the consumption $\left(\Delta_{c t}\right)$. In view of the above discussion, the dynamic consumption function that reflects the retail consumer behaviour for particular products may be estimated as (deriving from Equation (1)):

$$
\Delta_{c t}=\beta_{0}+\beta_{1}(L) u_{\mathrm{t}-1}+\beta_{2}(L) \Delta y_{\mathrm{t}}+\beta_{3}(L) \Delta w_{\mathrm{t}}+\beta_{4}(L) \Delta r_{\mathrm{t}}+\varepsilon_{\mathrm{t}}
$$


where $\Delta$ is the change factor, $r$ is the concentration ratio of retail stores in a given location and $\varepsilon_{\mathrm{t}}$ is a random error term. The test of this model requires time series data to be analysed for trend values, taking $(L)$ as polynomial log operator. It has been observed in previous studies that value to expenditure ratios increase consumer sensitivity in volume of buying and driving repeat buying decisions for the regular and high-tech products (Carroll and Dunn, 1997).

\section{Framework of hypotheses}

The store-person associations can also have a more personal nature. Stores can be associated with persons who use or used that particular store, e.g. a close friend or a family member. Also, stores received as gifts can also be associated with the person from whom the gift was received. These person associations serve to animate the store as a vital entity in the minds of the consumers. Consumers often feel vulnerable if they are not fully informed about the product attributes and given overwhelming commercial information. The type of relationship that customers possess with the stores based on the loyalty levels is an extremely significant parameter for the marketers. Duncan and Moriarty (1998) point out that each of the new-generation marketing approaches include customer focused, market-driven, outside-in, one-to-one marketing, data-driven marketing, relationship marketing, integrated marketing and integrated marketing communications that emphasise two-way communication through better listening to customers and the idea that communication before, during and after transactions can build or destroy important store relationships.

Although variety seeking leads to the novelty, abruptness and forgoing the monotony of repetitive use of the same store and product, such behaviour may involve risk of buying unfamiliar store products. This may also lead to the post-purchase dissatisfaction and customer may undergo a financial loss and emotional disquiet. This situation leads to perceived risk and affects the comprehensiveness of purchase-decision process and information processing ability of consumers. Hence it may be hypothesised as:

H1: The perceived risk and the preference of the store name are positively associated with the decision process of the customer to purchase an untried store.

The dimensions of store differences are defined by extending the dimensions of store communication and human personality to the domain of stores. One way to conceptualise and measure human personality is the trait approach, which states that personality is a set of traits (Anderson and Robin, 1986). A trait is defined as 'any distinguishable, relatively enduring way in which one individual differs from others' (Guilford, 1973). It has been argued in the above studies that store difference as perceived by the consumers influence their motivation for variety seeking. In absence of an appropriate communication on different values of competing stores, consumers may not distinguish strategies in seeking alternatives to their regular consumption pattern, and they will stick to stores that they have been using. Under such situations a large proportion of consumer store perception is obtained under low-involvement conditions and is therefore not consciously processed by the consumer's brain. Such associations tend to be stored in terms of metaphors and importantly, they tend to aggregate in clusters. The consumers feel that some stores are 
believed to offer better quality and value than some others if the perceived store difference is high. Hence, the variety seeker may find potential to acquire higher value in trying an unfamiliar store and lessen the randomness of variety-seeking behaviour. The following hypothesis is therefore framed:

H2: The intention of the consumers to depend on the store name is associated to the perceived differences in the stores by the consumer towards making decision to purchase an unfamiliar or new store.

Both corporate and product-dominant structures have been evolving towards hybrid structures. Firms with corporate dominant structures have been adding stores at other levels, e.g. the house or product level, to differentiate between different product divisions. Product-dominant structures may be described in reference to the multiple local stores that are moving towards greater integration or coordination across the markets through corporate endorsement of local products. These companies also vary in the extent to which they had clearly articulated international store architecture to guide this evolution. For example, some lay out the different levels at which stores were to be used, the inter-relation between stores at different levels, the geographic scope of each store and the product lines on which a store was to be used, while others had few or no guidelines concerning international storeing (Rajagopal and Sanchez, 2004). The factors like corporate skills in handling the complexities in the process of product development also influence the store decisions of consumers and a standardised product development process and user-friendly technology tend to give a sense of understanding to the consumers about difference in the process among the competing products. Consequently, consumers give less weight to the store name in the process of making purchase decision. Under such situation, the following hypothesis may be stated:

H3: Consumers give more weight to the store name in making decision to purchase an unfamiliar store product when there is greater difference in the production process followed by the companies.

A perspective from resource-advantage theory (Hunt and Morgan, 1995) is used to formulate expectations on the degree to which the use of information on customer value, competition and costs contribute to the success of a price decision. It is argued that the success of these practices is contingent on the relative customer value the firm has created and the degree to which this position of relative value is sustainable in the competitive market place. The value of corporate store endorsement across different products and product lines, and at lower levels of the store hierarchy also needs to be assessed as a customer value driver. Use of corporate store endorsement either as a name identifier or as a logo identifies the product with the company and provides reassurance for the customer (Rajagopal and Sanchez, 2004). The company association can enhance customers' anticipated value towards taking a decision to buy an unfamiliar store by eliciting more emotional and social values and generate 'me too' feeling. Accordingly, the consumers seeking variety may get associated with the store to achieve higher satisfaction. Hence the hypothesis may be set as:

H4: The store name plays a significant role in the purchase decisions on unfamiliar stores if the store name and company association enhance the customers' satisfaction and augments their value. 
In the high customer value framework, the firm ensures diminished costs to serve (Knox, 1998) and exhibits reduced customer price sensitivities. A database-driven approach, customer tenure in reference to the length of a customer's relationship and values retention with a company have often been used to approximate the loyalty construct (Ganesh et al., 2000; Reinartz and Kumar, 2000, 2002). Hence the relationship marketing with a customer value orientation thrives on the concept that raises the length of the customer-company relationship which contributes in optimising the profit for the firm (Reichheld and Sasser, 1990). However, the contributions of long-life customers were generally declining and in a non-contractual setting short-life but high revenue customers accounted for a sizeable amount of profits (Reinartz and Kumar, 2000).

\section{Study design}

To measure the influence of store name on variety-seeking behaviour of customers for making buying decision towards an unfamiliar store, a preliminary investigation has been conducted in 22 stores in 4 shopping malls. The data was collected on 24 questions closely related towards influencing the customer values. The major variables identified for the data collection include cognitive perspectives of customer satisfaction and corporate strategies applied in positioning the new products for gaining optimal market share and aggregate returns on consumptions. The information pertaining to the broad frame of these variables were subjected to decision filters at various levels of customers' decision-making process and major variables were chosen for data analysis. Data has been collected from 300 respondents purposively selected, who were involved in buying different categories of products at chosen retail autoservice stores in Mexico City administering a semi-structured questionnaire. The respondents involved in buying products in seven different categories including processed food (3), cosmetics (2) and dairy products (2). In all, the customer buying across seven products in the retail outlets have been covered under this study. The data of 31 respondents were omitted from the data analysis due to paucity of information. The respondents were involved in buying the new products introduced in five consumer products categories which include food and beverages, apparel, cosmetics, toys and household electronics. In all, the data of 269 observations were analysed in this study. The respondents of the study were categorised in reference to the magnitude and direction to the broad answers to the questions such as influence of store or company name associated in buying the unfamiliar store as positive, negative, indifferent. This process led to three principal clusters of respondents as stated below:

Cluster- $C_{l}$ : Consumers who recognise positive influence of the store name or company name association in buying of unfamiliar stores.

Cluster- $C_{2}$ : Consumers who recognise negative influence of the store name or company name association in buying of unfamiliar stores.

Cluster- $C_{3}$ : Consumers who are not sure of the significance of the store name or company name association in buying of unfamiliar stores have been clustered as indifferent.

There are four independent variables used in the study store extension, extension information, perceived risk and parent store name. The dependent variable is measured as consumer perspectives on decision-making towards store extension products. The entire 
variable was measured by multiple items. A large number of statements have been structured to acquire the agreement or disagreement of the respondents towards their cognitive behaviour associated with the store and company name. The statements had a seven-point scale ranging from 'fully disagree (1)' to 'completely agree (7)'.

\section{Results and discussion}

The data collected from respondents was tested for its reliability applying the Cronbach's $\alpha$ test. Variables derived from test instruments are declared to be reliable only when they provide stable and reliable responses over a repeated administration of the test. It has been observed from the test results that the variables associated with the perceived risk (4), perceived store difference (5) and store and company name (5) showed the highest reliability. The significance tests and clustered mean values of the selected variables have been exhibited in Table 1.

The Wilk's Lambda, a multi-variate analogue of the coefficient of alienation, was also tested for the major variables which derived significant values and upon individual consideration of the predicators, all showed a statistically significant influence on the dependent variable except the variable denoting the expertise associated with the company which enhances the customers' satisfaction and augments their value $(p=0.218,>0.05)$. The mean values on the variable segments of the clusters of respondents reveal that there is largest gap between $C_{1}$ and $C_{2}$ on perceived risk and a considerable separation may also be seen on perceived store difference between the same clusters. However, the difference among all the three clusters $\mathrm{C}_{1}, \mathrm{C}_{2}$ and $\mathrm{C}_{3}$ are marginal in reference to the other two variable segments - store and company name association and customer value enhancement. The results exhibited in Table 1 show that the statistical measurements of variable segments support all hypotheses framed in the study except $\mathrm{H} 4$.

The analysis of consumer perceptions in relation to the seven category of products covered under the study as exhibited in Table 2 show that there exist smaller gaps between respondent clusters $\mathrm{C}_{1}$ and $\mathrm{C}_{2}$ in product categories $\mathrm{P}_{1}$ and $\mathrm{P}_{2}$. However, the gap has been found larger in the product categories $\mathrm{P}_{3}$ as compared to the other categories of products. This suggests that customer pays higher significance to the band name and company association in purchase of unfamiliar store in these categories. However, the store name and a company association were not regarded as important in case of buying detergents and toiletries in the product of categories $\mathrm{P}_{4}$ and $\mathrm{P}_{5}$, as the respondent felt that the store name and company association may not contribute significantly to augment the customer satisfaction and add psychometric values in using the products. The pooled inter-group matrices have been exhibited in Table 3 with reference to the four variable segments discussed in Table 1.

The results of the correlation matrices indicate that there exists a lower degree correlation between the perceived risk and perceived store difference $\left(V_{1}, V_{2}\right)$, store name and perceived store difference $\left(V_{3}, V_{2}\right)$ and perceived risk and company name $\left(V_{1}, V_{3}\right)$. It may be observed from the above matrix that the coefficient has a maximum value of 0.394, which do not pose a serious concern of multi-collinearity. The eigenvalues have been computed to estimate the shared variance between the respective optimally weighted canonical variates of dependent and independent variables. The canonical correlations analysis has been derived considering the set of dependent and independent 
variables representing the canonical functions. The analysis of the data indicates that the first function $\left(F_{1}\right)$ has the highest eigenvalue $(0.427)$ which accounts for $89.36 \%$, while the second function $\left(\mathrm{F}_{2}\right)$ has shown relatively smaller eigenvalue $(0.138)$ with $11.64 \%$ of the explained variance. The analysis reveals that the canonical correlations for $F_{1}$ and $F_{2}$ are 0.637 and 0.174 , respectively. Accordingly, it may be stated that the $F_{1}$ is superior to $\mathrm{F}_{2}$. Table 4 exhibits the standardised canonical coefficients of discriminant functions and functions at group centroids.

Table 2 Cluster means on the variable store name association by product categories

\begin{tabular}{lccc}
\hline & \multicolumn{3}{c}{ Respondent clusters } \\
\cline { 2 - 4 } Product categories & $C_{1}$ & $C_{2}$ & $C_{3}$ \\
\hline Processed food $\left(\mathrm{P}_{2}\right)$ & 3.65 & 3.42 & 3.79 \\
Cosmetics $\left(\mathrm{P}_{3}\right)$ & 4.17 & 4.82 & 3.76 \\
Dairy products $\left(\mathrm{P}_{6}\right)$ & 3.46 & 3.68 & 3.83 \\
\hline
\end{tabular}

Table 3 Inter-group correlation matrices

\begin{tabular}{|c|c|c|c|c|}
\hline Variable segments & $\begin{array}{l}\text { Risk perceived by } \\
\text { the customers }\end{array}$ & $\begin{array}{l}\text { Perceived store } \\
\text { difference }\end{array}$ & $\begin{array}{l}\text { Store and } \\
\text { company name } \\
\text { association }\end{array}$ & $\begin{array}{l}\text { Customer value } \\
\text { enhancement } \\
\text { through store name } \\
\text { and company } \\
\text { association }\end{array}$ \\
\hline $\begin{array}{l}\text { Risk perceived by the } \\
\text { customers }\end{array}$ & 1.000 & & & \\
\hline Perceived store difference & 0.380 & 1.000 & & \\
\hline $\begin{array}{l}\text { Store and company name } \\
\text { association }\end{array}$ & 0.371 & 0.394 & 1.000 & \\
\hline $\begin{array}{l}\text { Customer value } \\
\text { enhancement through } \\
\text { store name and company } \\
\text { association }\end{array}$ & 0.227 & 0.210 & 0.215 & 1.000 \\
\hline
\end{tabular}

Note: The absolute value of correlations $\leq 0.21$ is significant at the 0.10 level, between 0.22 and 0.37 is significant at 0.05 levels, and above 0.39 is significant at 0.01 levels.

Table 4 Canonical values and fit of the model

\begin{tabular}{|c|c|c|c|c|c|c|c|}
\hline \multirow{2}{*}{$\begin{array}{l}\text { Canonical } \\
\text { functions }\end{array}$} & \multicolumn{4}{|c|}{ Variable segments } & \multicolumn{3}{|c|}{ Respondent clusters } \\
\hline & $V_{1}$ & $V_{2}$ & $V_{3}$ & $V_{4}$ & $C_{l}$ & $C_{2}$ & $C_{3}$ \\
\hline$\overline{F_{1}}$ & 0.837 & 0.577 & 0.061 & 0.316 & 0.874 & -0.152 & -0.249 \\
\hline $\mathrm{F}_{2}$ & -0.173 & 0.264 & 0.326 & 0.632 & 0.114 & 0.227 & -0.106 \\
\hline
\end{tabular}

Note: The absolute value of correlations between $\geq 0.22$ and 0.22 is significant at the 0.10 level, between 0.26 and 0.32 is significant at 0.05 levels, and above 0.32 is significant at 0.01 levels. 
The results show that the value of coefficients among the variable segments $V_{1}$ and $V_{2}$ are of higher degree for canonical function $F_{1}$ which describes that these two variables perceived risk and perceived store difference are basically associated with the function. Similarly, the company name and customer value variables are associated with the function $F_{2}$ as the coefficients show relative by higher values. In reference to the clusters of respondents, the segment $\mathrm{C}_{1}$ which represents positive influence of store name in consumers' behaviour of respondents show highest value on function $F_{1}$ while $C_{2}$ represents the lowest value as the function $F_{1}$ is associated with perceived risk and perceived store difference variables.

Such results indicate that higher perceived store risk and store difference may provide more confidence on the company name while making decisions towards buying the products of an unfamiliar store.

Figure 1 exhibits the consumer perceptions matrix for the perceived risk, store difference and store name and customer values associated with the store in reference to the clusters of respondents. The data was analysed using a 2 (perceived risk and store difference: high vs. low) $\times 2$ (store name influence: familiar vs. unfamiliar). The results show that the coefficient of correlations for the high perceived risk and store difference has led to quick adaptation of familiar stores in all the respondents' categories while delayed adaptation for the unfamiliar stores in the $\mathrm{C}_{1}$ and $\mathrm{C}_{2}$ categories as compared to other relationships. These results support the hypotheses $\mathrm{H} 1, \mathrm{H} 2$ and $\mathrm{H} 4$ in reference to the influence of store name towards making buying decisions on unfamiliar stores (H3).

Figure 1 Consumer perception matrix on influence of store name and buying decisions towards unfamiliar stores

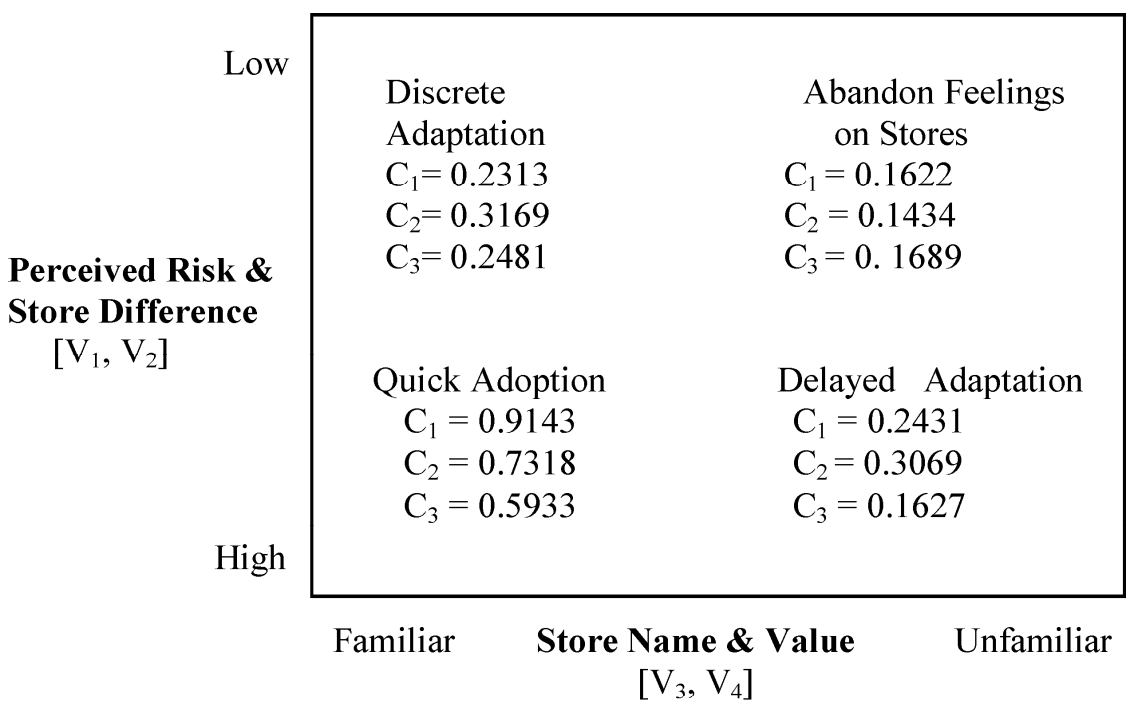

Values represent pooled coefficient of correlation in reference to the clusters of respondents $\left(\mathrm{C}_{1}, \mathrm{C} 2\right.$ and $\left.\mathrm{C}_{3}\right)$ for all products category in the sales outlets covered under study. 


\section{Managerial implications}

Consumer perceptions on store name and values associated therewith may lead to a significant impact on penetration build for new stores and for stimulating growth in existing stores provided, they are anchored on a well-defined activation platform that builds store equity. However, a marketer can manipulate the company name within certain limits. The companies may need to consider the impact of increased reliance of consumers on the store name towards the promotion of new stores as this may discourage to go for higher promotional budgets for the new stores of the company. Hence, managers may aim at achieving the economies of scale if the company's new stores are architected around the influence of the name of mother store. It may be required for a company to invest on appealing communication strategies for creating awareness on the unfamiliar stores to influence the decision of consumers towards buying those stores that they have not tested before. The company may also need to consider emphasising an integrated promotion strategy for new stores in reference to attributes, awareness, trial, availability and trial principle. Besides, the company should also observe the parameters that consumers use in determining the corporate image and store performance. However, it is necessary for the managers to consider that consumer perceptions are one of the core dimensions of store equity, which refers to the emotional side of a store image and is created by all experiences of consumers with a store. The store image is largely constituted by the corporate reputation and company name which becomes motivation for the consumers towards making decision on the new stores.

At the retail point of purchase convergence of customer loyalty, value for money and competitive product advantages drives the loyalty of retail stores. Success of retail firms grow with the customer satisfaction, brand value, repeat buying behaviour and increase in the sales of products. By making effective pre-purchase interaction with the customers, planning appropriate sales promotions, user-friendly packaging, generating adequate shopping arousal and focusing in-store ambience, marketers can effectively serve various interests of the manufacturer, the retailer and the customers. A strategic focus considering how customers and competitors will react to any promotional effort, as well as the message delivered and the stature in the marketplace of the brand delivering should be developed by the firms to strengthen and streamline the pre-purchase promotions in marketplace. Hence, managers should not only tailor promotion programmes successfully to target customers, but also skillfully monitor its implementation through customer culture and competition challenges.

\section{Conclusions}

It has been observed in this study that the perceptions on store name in reference to store risk and store differences have been the prime factors in making buying decision for new stores among the consumers. More attention is being paid by the consumers to ascertain the store name associated with the unfamiliar stores as the consumer feel high risk averse and entangle in decision-making with perceived store differences. The perceptions of the consumers on the corporate reputation and values associated therewith also influence the level of confidence on the store name. The influence of store name would be higher if the consumers perceive that the companies vary in delivering the product with a competitive advantage and augment their level of satisfaction. The study revealed that 
high perceived risk and store difference induce the consumers to review the store name in the process of making buying decisions. Like many other empirical studies, this research might also have some limitations in reference to sampling, data collection and generalisation of the findings. The samples drawn for the study may not be enough to generalise the study results. However, results of this study may indicate similar pattern of shopping behaviour of urban consumers in shopping malls also in reference to other Latin American markets.

\section{Future research prospects}

Future research could examine issues related to the customer perceptions of quality and dealer performance. The impact of environmental variables on the quality perceived-quality performance relationship may also be considered given the findings of this study. Identifying the variables that have an intervening effect on the quality performance relationship may provide both academics and managers with potentially compelling answers to the question of why dealer-oriented quality improvement programmes sometimes do not succeed. Market orientation of a firm has significant influence on the behaviour and attitudes of its sales force which can be studied in relation to the cognitive and economic factors related to a business firm.

\section{References}

Aaker, D. (1991) Managing Store Equity. New York: The Free Press.

Aaker, D. and Joachimsthaler, E. (2000) Store Leadership. New York: The Free Press.

Agarwal, M. and Rao, V. (1996) 'An empirical comparison of consumer based measures of store equity', Marketing Letters, Vol. 7, No. 3, pp.237-247.

Ambler, T. (2000) Marketing and the Bottom Line. London: FT Prentice Hall.

Anderson, P.M. and Robin, L.G. (1986) Marketing Communications: Advertising, Sales Promotion, Public Relations, Display and Personal Selling. Englewood Cliffs, NJ: Prentice Hall.

Andrews, R.L. and Currim, I.S. (2002) 'Identifying segments with identical choice behaviors across product categories: an inter-category logit mixture model', Int. J. Research in Marketing, Vol. 19, No. 1, pp.65-79.

Baldinger, A. and Robinson, J. (1996) 'Store loyalty: the link between attitude and behavior', Journal of Advertising Research, Vol. 36, No. 6, pp.22-35.

Bass, F.M. (1974) 'The theory of stochastic preference and store switching', Journal of Marketing Research, Vol. 11, pp.1-20.

Batra, R., Lehmann, D. and Singh, D. (1993) 'The store personality component of store goodwill: some antecedents and consequences', in D.A. Aaker and A.L. Biel (Eds.), Brand Equity and Advertising. Hillsdale, NJ: Lawrence Erlbaum Associates, pp.67-82.

Berlyne, D.E. (1960) Conflict, Arousal and Curiosity. New York, NY: McGraw-Hill.

Berné, C., Mugica, J.M. and Yague, J.M. (2001) 'The effect of variety seeking on customer retention in services', Journal of Retailing and Consumer Services, Vol. 8, No. 6, pp.335-345.

Blackston, M. (1992) 'Observations: building store equity by managing the store's relationship', Journal of Advertising Research, Vol. 32, No. 3, pp.79-83.

Bliss, C. (1988) 'A theory of retail pricing', Journal of Industrial Economics, Vol. 36, No. 4, pp.375-391. 
Brassington, F. and Pettitt, S. (2002) Principles of Marketing (3rd ed.). Prentice Hall: Pearson Education.

Carroll, C.D. and Kimball, M.S. (1996) 'On the concavity of the consumption function', Econometrics, Vol. 64, No. 4, pp.981-992.

Carroll, D. and Dunn, W.E. (1997) 'Unemployment expectations', Working Paper No. 6081, NBER.

Chaudhuri, A. and Holbrook, M.B. (2001) 'The chain of effects from store trust and store effect to store performance: the role of store loyalty', Journal of Marketing, Vol. 65, pp.81-93.

Dall'Olmo, R. et al. (1997) 'The viability of attitudinal repeat rates', Int. J. Research in Marketing, Vol. 14, No. 5, pp.437-450.

Deaton, A. (1992) Understanding Competition. Oxford: Oxford University Press.

Dick, A.S. and Basu, K. (1994) 'Customer loyalty: towards an integrated conceptual framework', Journal of the Academy of Marketing Science, Vol. 22, pp.99-113.

Dobson, J. (2007) 'Aesthetics as a foundation for business activity', Journal of Business Ethics, Vol. 72, No. 1, pp.41-46.

Duncan, T. and Moriarty, S.E. (1998) 'A communication based marketing model for managing relationships', Journal of Marketing, Vol. 62, pp.1-13.

Erdogan, Z. and Baker, M. (2000) 'Celebrity endorsement: advertising agency manager's perspective', The Cyber Journal of Sport Marketing, Vol. 13, pp.1-15. Available at: www.cjsm.com.

Ganesh, J., Arnold, M.J. and Reynolds, K.E. (2000) 'Understanding the customer base of service providers: an examination of the difference between switchers and stayers', Journal of Marketing, Vol. 64, pp.65-87.

Guilford, J. (1973) 'On personality', in W. Mischel (Ed.), Introduction to Personality. New York: Holt Rinehart and Wilson, pp.22-25.

Gupta, S., Lehmann, D.R. and Stuart, J.A. (2003) 'Valuing consumers', HBS Marketing Research Paper No. 03-08.

Huber, J. and Reibestein, D. (1978) 'Attitudes measures and choice frequency: some pitfalls to be avoided', in J.C. Maloney (Ed.), Attitude Research Plays for High Stakes. Chicago, IL: American Management Association.

Hunt, S.D. and Morgan, R.M. (1995) 'The comparative advantage theory of competition', Journal of Marketing, Vol. 59, pp.1-15.

Inman, J.J. (2001) 'The role of sensory-specific satiety in attribute level variety seeking', Journal of Consumer Research, Vol. 28, No. 1, pp.105-121.

Jacoby, J. and Chestnut, R. (1978) Store Loyalty. New York: Hon Wiley \& Sons.

Jacoby, J. and Kyner, D.B. (1973) 'Store personality versus repeat purchasing', Journal of Marketing Research, Vol. 10, pp.1-9.

Knox, S. (1998) 'Loyalty store segmentation and the customer development process', European Management Journal, Vol. 16, No. 6, pp.729-737.

Leuba, C. (1955) 'Towards some integration of learning theories: the concept of optimal simulation', Psychological Reports, Vol. 1, pp.27-33.

Mackay, M.M. (2001) 'Evaluation of store equity measures: further empirical results', Journal of Product and Store Management, Vol. 10, No. 1, pp.38-51.

Maddi, S.R. (1968) 'The pursuit of consistency and variety', in R.P. Abelson et al. (Eds.), Theories of Cognitive Consistency-A Sourcebook. Chicago, IL: Rand McNally.

McAlister, L. (1982) 'A dynamic attribute satiation model of variety seeking behavior', Journal of Consumer Research, Vol. 9, pp.141-150.

McAlister, L. and Pessemier, E.A. (1982) 'A dynamic attribute satiation model of variety-seeking behavior’, Journal of Consumer Research, Vol. 9, pp.311-322. 
Michaelidou, N., David, A.C. and Sally, D. (2005) 'Characteristics of marketing channels: a theoretical framework', The Marketing Review, Vol. 5, No. 1, pp.45-57.

Moriarty Jr, R.T. and Moran, U.H. (1990) 'Managing hybrid marketing systems', Harvard Business Review, Vol. 68, No. 6, pp.146-155.

Nijssen, E.J. (1999) 'Success factors of line extensions of mast moving consumer goods', European Journal of Marketing, Vol. 33, Nos. 5-6, pp.45-47.

Odin, Y., Odin, N. and Valette-Florence, P. (2001) 'Conceptual and operational aspects of store loyalty: an empirical investigation’, Journal of Business Research, Vol. 53, pp.75-84.

Oliver, R. (1999) 'Whence consumer loyalty?', Journal of Marketing, Vol. 63, Special Issue, pp.33-44.

Pearson, S. (1996) Building Stores Directly. London: Macmillan Business.

Rajagopal and Sanchez, R. (2004) 'Conceptual analysis of store architecture and relationships within product categories', Journal of Store Management, Vol. 11, No. 3, pp.233-247.

Redenbach, A. (2000) 'A multiple product endorser can be a credible source', The Cyber Journal of Sport Marketing, Vol. 13, pp.1-10.

Reichheld, F. (1996) The Loyalty Effect. Boston: Harvard Business School.

Reichheld, F. and Sasser, W.E. (1990) 'Zero defections: quality comes to services', Harvard Business Review, September-October, pp.105-111.

Reinartz, W.J. and Kumar, V. (2000) 'On the profitability of long-life customers in a noncontractual setting: an empirical investigation and implementation for marketing', Journal of Marketing, Vol. 64, No. 4, pp.17-35.

Reinartz, W.J. and Kumar, V. (2002) 'The mismanagement of customer loyalty', Harvard Business Review, July, pp.4-12.

Rundle-Thiele, S. and Bennett, R. (2001) 'A store for all seasons: discussion of store loyalty approaches and their applicability for different markets', Journal of Product and Store Management, Vol. 10, No. 1, pp.25-37.

Rust, R., Zeithaml, V. and Lemon, K. (2000) Driving Customer Equity. New York: The Free Press.

Tauber, E.M. (1998) 'Store leverage: strategy for growth in a cost-control world', Journal of Advertising Research, Vol. 28, No. 4, pp.26-30.

Teller, C. (2008) 'Shopping streets versus shopping malls - determinants of agglomeration format attractiveness from the consumers' point of view', The International Review of Retail, Distribution and Consumer Research, Vol. 18, No. 4, pp.381-403.

Tversky, A. and Kahnman, D. (1981) 'The framing decisions and psychology of choice', Science, Vol. 211, pp.453-458.

Van Trijp, H.C.M., Hoyer, W.D. and Inman, J. (1996) 'Why switch? Product-category level explanations for true variety-seeking behavior', Journal of Marketing Research, Vol. 33, pp.281-192.

Venkatesan, M. (1973) 'Cognitive consistency and novelty seeking', in S. Ward and T.S. Robertson (Eds.), Consumer Behavior: Theoretical Resources. Englewood Cliffs, NJ: Prentice Hall, pp.355-384.

Zuckerman, M. (1979) Sensation Seeking: Beyond the Optional Level of Arousal. Hillsdale, NJ: Lawrance Erlbaum Associates.

\section{Bibliography}

Berry, L.L. (2000) 'Cultivating service store equity', Journal of the Academy of Marketing Science, Vol. 28, No. 1, pp.79-83.

Keller, K.L. (1993) 'Conceptualizing, measuring and managing customer based store equity', Journal of Marketing, Vol. 57, pp.1-22. 
Krake, F.B.G.J.M. (2005) 'Successful store management in SMEs: a new theory and practice hints', Journal of Product and Store Management, Vol. 14, No. 4, pp.228-238.

Nandan, S. (2005) 'An exploration of the store identity-store image linkage: a communication perspective', Journal of Store Management, Vol. 12, No. 4, pp.264-278.

Rajagopal (2005) 'Measuring variability factors in consumer values for profit optimization in a firm: a framework for analysis', Journal of Economics and Management, Vol. 1, No. 1, pp.85-103.

Sharp, B. (1995) 'Store equity and market based assets of professional service firms', Journal of Professional Services Marketing, Vol. 13, No. 1, pp.3-13.

Yoo, B. and Donthu, N. (2001) 'Developing and validating a multidimensional consumer based store equity scale', Journal of Business Research, Vol. 52, pp.1-14. 